The Geneva Papers on Risk and Insurance, 16 (No. 61, October 1991), 500-503

\title{
A Lawyer's Vision, and a Claimant's Nightmare
}

\author{
by Gerfried E. Brunn*
}

\section{A possible scenario}

The following case report may or may not be written at some time in the future:

On the 35th May, 1995, the mv Juliett, destined for Rotterdam, collided on the river Rhine with a pier of the Hohenzollern Bridge at Cologne, a busy railway bridge over which at the time of the accident a fully occupied Intercity Train was passing. The vessel's dangerous cargo exploded. The owner and crew were killed. A substantial number of persons were severely injured. There was also substantial damage to the bridge, to the train, to other vessels on the river, as well as to their cargoes, and to the environment. The total amount of the loss was immense.

The $m v$ Juliett's tonnage was 2.800 tons. It was powered by a $2.200 \mathrm{~kW}$ engine. The Federal Republic of Germany had ratified the Strasbourg Convention on Limitation of Civil Liability on Inland Navigation Vessels (CLNI). The shipowner was consequently liable, under article 6 of CLNI, for personal injuries up to $2.1 \mathrm{M}$ Special Drawing Rights (SDR) (equivalent to about US $\$ 2.9 \mathrm{M}$ ), and for property damage up to SDR $1.05 \mathrm{M}$ (or US $\$ 1.45 \mathrm{M})$. Total liability under CLNI therefore amounted to US $\$ 4.35 \mathrm{M}$.

Fortunately for the victims, the Federal Republic of Germany had also ratified the Convention on Civil Liability for Damage Caused During Carriage of Dangerous Goods by Road, Rail or Inland Navigation Vcssels (CRTD), under articlc 9 of which the shipowner was liable for personal injuries up to SDR $8 \mathrm{M}$ (or US $\$ 11.1 \mathrm{M}$ ) and for other loss up to SDR $7 \mathrm{M}$ (or US $\$ 9.7 \mathrm{M}$ ). In compliance with CRTD, the shipowner had obtained liability insurance coverage in the amount of SDR $15 \mathrm{M}$.

At first, it was assumed that the accident had been caused by a malfunction of the vcssel's electronic steering equipment. Further investigation showed that there was no defect in the equipment. Rather, a farewell letter was found indicating that the vessel's owner had caused the collision deliberately to commit suicide.

\footnotetext{
* Gerfried E. Brunn, Dr. jur., is Deputy General Secretary of the German Transport Insurers' Association (DTV) in Hamburg, and Liaison Officer, International Organizations, of the International Union of Marine Insurance (IUMI). The following is a revised and updated version of an oral report presented to the Council of IUMI in London in September 1990.
} 
In view of the accident having been caused by an intentional act of the owner, the owner could not rely on the limitation of liability under CRTD (article 10). The owner was penniless, of course.

For the owner's liability insurers, the situation was as follows: Irrespective of the fact that the owner had for himself forfeited the liability limits under CRTD, the insurers could still rely on them (article 7 para. 8). The language of this provision follows that of the International Convention of Civil Liability for Oil Pollution Damage (CLC). Under German insurance law, however, liability insurance does not, and may not, cover claims for damage caused deliberately by the policyholder, even if the insurance is required by law. Consequently, the insurers, despite having issued an insurance certificate under CRTD, did not have to pay any of the claims.

The claimants's lawyers then invoked the EC Directive on the Liability of Suppliers of Services, which provides (in its article 1) that a supplier of a service shall be liable for personal injuries and property damage caused by a fault committed in the performance of the service. The directive is designed to protect not only the persons or property who are the object of the service but also unrelated third parties. Service is defined (in article 2) as "any transaction carried out on a commercial basis or by way of a public service and in an independent manner, whether or not in return for payment", not involving the manufacture of movable property or the transfer of rights in rem or intellectual property rights. The directive imposes on the supplier of the service the burden of proving the absence of a "fault" (article 1 para. 2).

The definition of "service" includes international transports. The directive is, however, according to its article 2 para. 3 , inapplicable to "damage covered by liability arrangements governed by international agreements ratified by the Member States or by the Community". It is not clear whether this includes only agreements ratified by all member states or whether ratification by the member state whose law is applicable would be sufficient. The provision would not exempt liability regimes based on international agreements and incorporated into national laws without formal ratification, as is the case in Germany with respect to the Hague-Visby Rules. Further, it would seem that the exemption is intended to apply only to those types of damage for which an international agreement actually provides liability, and that the provisions of the directive would still govern where they are more generous in defining compensable damages.

Whether or not the directive applies and whether or not it overrides international agreements, it did not help the claimants in our case. The vessel owner, as mentioned, was penniless. We must also assume that he had not been able to obtain liability insurance coverage, the risk under the directive being considered uninsurable by all major insurers and $\mathbf{P} \&$ I Clubs. Even if he had been insured, the claims resulting from his intentional act would not be covered.

The owners of cargoes damaged on the $m v$ Juliett and other vessels affected by the accident did not fare any better with their claims under the Hague Rules, the Hague-Visby Rules, the Hamburg Rules and the MT Convention. Not having been ratified by Germany, these agreements would be overruled by the EC directive.

The claimants' lawyers now sat back in their chairs thinking. Then they read the directivc again and noticed that "supplier of services", as defined in article 3 para 1 of the EC 
directive, included "any natural or legal person governed by private or public law who, in the course of his professional activities or by way of a public service, provides a service...".

Concluding that that included legislative acts, the lawyers proceeded to institute legal proceedings on behalf of their clients against:

- the government of the Federal Republic of Germany for having ratified the CRTD and for having issued for $m v$ Juliette an insurance certificate implying that coverage existed for all claims, including those arising from wilful acts of the insured;

- the European Community for having adopted the Directive on the Liability of Suppliers of Services, knowing from statements of insurance industry representatives that the liability risk created by the directive would not be insurable and that adoption of the directive would render most of the conventions in the field of international transport inapplicable;

- the UN Economic Commission for Europe for having adopted the CRTD, not recognizing that liability insurance would not cover the transporter's liability for wilful acts.

Decisions on these court actions are expected around the year 2022. Legal costs will substantially increase the total amount of the loss.

\section{Challenges to be met}

The case is purely fictional, of course. So far, carriage of dangerous goods on inland navigation vessels has not led to any catastrophic accidents. In fact, no losses of any kind caused by dangerous cargo have become known. It is to be hoped that such losses will never occur. The case should, however, demonstrate the legal problems that might arise should a serious accident occur in the future.

The CLNI was adopted by the Rhine Central Commission in November 1988 and has not been ratified by any state. Consequently, under current German law, the shipowner's liability is still limited to the value of the vessel and the freight claims.

The CRTD was adopted by the Inland Transport Committee of the UN Economic Commission for Europe in Geneva in October 1989 and has not been ratified by any state. In contrast to the CLNI, which follows ocean marine conventions in differentiating liability limits by tonnage and engine power, the CRTD prescribers uniform limits.

This will, I fear, lead to insurance premiums beyond the range that can be paid by individual vessel owners. For many individuals and for small fleets, the liability risk created by CRTD will therefore most likely be economically uninsurable.

The risk of liability for damage resulting from wilful misconduct is at present not even covered by $\mathrm{P} \&$ I Clubs. A revision conference might try to find an acceptable solution.

The EC Directive on Liability of Suppliers of Services is at present only a proposal submitted to the Council by the Commission (OJ No. C 12, of 18th January 1991). It appears that the Commission will continue to push for its adoption, despite warning by IUMI and other industry organizations that the directive, if adopted in the form proposed, would have serious consequences in the field of international transports and that the liability risks created by the directive would possibly not be insurable.

The directive will, of course, not be applied to legislative acts. It could, however, force EC member states to withdraw from some international conventions regarding carriers' 
liability, with a consequent loss of uniformity of international transport law and detriment to world trade.

The CRTD has its impact primarily on Europe. However, transport on inland waterways will certainly become more important as traffic shifts back to waterways such as the river Elbe that were restricted for a long time, and road traffic is increasingly subjected to restrictions on grounds of environmental protection. Incidents involving dangerous goods may result in damage to goods in transit from non-European countries. Therefore, I recommend to all member associations to urge their governments to reconsider their possibilities to bring about a revision of the CRTD with respect to liability limits and the coverage in case of wilful misconduct.

The EC directive will not have a worldwide impact. It would, however, impair the unification of law already achieved in the field of international transport. IUMI's President has already expressed the great concern of IUMI to the EC Commission, but it would certainly be helpful if organizations from many countries within and outside the EC would persuade their governments to insist on a revision of the proposal that would at least provide for a clear and complete exemption for international transport.

Finally, to explain the name of the vessel involved in the fictional accident: Juliett is the code word for the signal "J", which means, "I am on fire and have dangerous cargoes on board: keep well clear of me". I think governments should keep clear of CRTD and the draft directive. IUMI's signal should be "Uniform": "You are running into danger". I hope IUMI's signal will be understood by governments. 